\title{
Response of the Arabian Sea to global warming and associated regional climate shift
}

\author{
S. Prasanna Kumar ${ }^{\mathrm{a}, *}$, Raj P. Roshin ${ }^{\text {a }}$, Jayu Narvekar ${ }^{\mathrm{a}}$, P.K. Dinesh Kumar ${ }^{\mathrm{b}}$, E. Vivekanandan ${ }^{\mathrm{c}}$ \\ a National Institute of Oceanography, Dona Paula, Goa 403 004, India \\ ${ }^{\mathrm{b}}$ Regional Center of NIO, Kochi 682 018, India

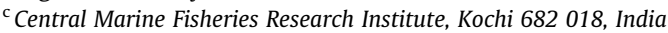

\section{A R T I C L E I N F O}

Article history:

Received 16 August 2008

Received in revised form 5 June 2009

Accepted 7 June 2009

\section{Keywords:}

Climate change

Arabian Sea

Sea surface temperature

Cyclones

Rainfall

Winter temperature

Wheat production

Food quantity

Vegetation cover

\begin{abstract}
A B S T R A C T
The response of the Arabian Sea to global warming is the disruption in the natural decadal cycle in the sea surface temperature (SST) after 1995, followed by a secular warming. The Arabian Sea is experiencing a regional climate-shift after 1995, which is accompanied by a five fold increase in the occurrence of "most intense cyclones". Signatures of this climate-shift are also perceptible over the adjacent landmass of India as: (1) progressively warmer winters, and (2) decreased decadal monsoon rainfall. The warmer winters are associated with a 16-fold decrease in the decadal wheat production after 1995, while the decreased decadal rainfall was accompanied by a decline of vegetation cover and increased occurrence of heat spells. We propose that in addition to the oceanic thermal inertia, the upwelling-driven cooling provided a mechanism that offset the $\mathrm{CO}_{2}$-driven SST increase in the Arabian Sea until 1995.
\end{abstract}

(c) 2009 Elsevier Ltd. All rights reserved.

\section{Introduction}

Global warming and human-induced climate change are the immediate threats to mankind and tropical regions are the most vulnerable to them. Global warming has different manifestations, such as increase in the number and severity of tropical cyclones (Emanuel, 2005; Webster et al., 2005), changing pattern of precipitation and increase of extreme rain events (Goswami et al., 2006; Zhang et al., 2007), melting of glaciers (Oerlemans, 1994) and associated sea level rise (Church, 2001; Meehl et al., 2005). In addition to these changes in the physical climate, the terrestrial as well as the aquatic ecosystem will also experience great pressure and undergo change (Meyer et al., 1999; Cramer et al., 2001). For example, variation in the length of a season may lead to mismatches between the key elements in an ecosystem such as flowering and nesting times, feeding period of young birds (Both et al., 2006). Similarly, a warming environment driven by rapid increase in the concentration of atmospheric carbon dioxide and ocean acidification may lead to coral bleaching (Hughes et al., 2003; Hoegh-Guldberg et al., 2007), while increased land temperature may lead to an increase in the tropical vector-borne diseases (Rogers and Randolph, 2000; Hopp and Foley, 2003) thus causing concern for human health. Recent studies showed that not only are the oceans

\footnotetext{
* Corresponding author. Tel.: +91 832 2450300; fax: +91 8322450608 .

E-mail address: prasanna@nio.org (S.P. Kumar).
}

becoming warmer at the surface, but there is penetration of the human induced warming into the deeper parts of the oceans (Barnett et al., 2005). However, it is presently unclear how the Arabian Sea is responding, except that it has warmed by about $0.5{ }^{\circ} \mathrm{C}$ during 1904-1994 (RupaKumar et al., 2002). In this paper we explore the response of the Arabian Sea to global warming and its possible impact on frequency and intensity of cyclones, summer monsoon rainfall, wheat production, land vegetation cover and frequency of heat spells.

\section{Material and methods}

\subsection{Study area}

The Arabian Sea is a tropical basin situated in the western part of the northern Indian Ocean $\left(0-25^{\circ} \mathrm{N}\right.$ and $\left.45-80^{\circ} \mathrm{E}\right)$ which is land locked in the north. It is forced by a semi-annually reversing wind system called monsoon. During winter (December-February), the weak $\left(\sim 5 \mathrm{~m} \mathrm{~s}^{-1}\right)$ northeast trade winds bring cool, dry continental air into the Arabian Sea, while during summer (June-September), the strong $\left(\sim 15 \mathrm{~m} \mathrm{~s}^{-1}\right)$ southwest winds brings moisture-laden maritime air into the Arabian Sea. In response to this wind reversal, the upper ocean circulation of the Arabian Sea also undergoes seasonal reversal. The Arabian Sea is biologically one of the most productive regions of the worlds' oceans (Ryther et al., 1966) due to the summer and winter blooms. The summer phytoplankton 
bloom occurs due to wind-driven upwelling (Smith and Codispoti, 1980; Banse, 1987; Brock and McClain, 1992) along the coast of Somalia, Arabia and southern part of the west coast of India, while the winter bloom driven by winter-cooling and convective mixing (Madhupratap et al., 1996; Prasanna Kumar et al., 2001a) occurs in the northern Arabian Sea.

\subsection{Data and analysis}

We used a variety of multi-disciplinary data from the Arabian Sea and the adjacent landmass of India to elucidate the signature of global warming and regional climate-shift. The monthly mean sea surface temperature (SST) data in the Arabian Sea $\left(0-25^{\circ} \mathrm{N}\right.$ and 45-80 ${ }^{\circ}$ E) were extracted for the period 1960-2006 from three different sources: (1) the International Comprehensive OceanAtmosphere Data Set (ICOADS) (Woodruff et al., 2005) (http:// www.cdc.noaa.gov/cdc/data.coads.1deg.html), (2) NOAA SST data (Reynolds et al., 2002) and (3) Kaplan SST data (Kaplan et al., 1998), both provided by the NOAA/OAR/ERSL PSD, Boulder, Colorado, USA from their website http://www.cdc.noaa.gov/in (Reynolds et al., 2002). From the monthly mean SST annual mean SST anomaly was computed for further analysis. The strong El Nino years (1972-1973, 1982-1983, 1991-1992 and 1997-1998) (see http://ggweather.com/enso/oni.htm) as well as Indian Ocean Dipole (IOD) years (1961, 1963, 1967, 1972, 1982, 1994, 1997 and 2006) (see http://www.marine.csiro.au/ mcintosh/ENSO_IOD_years.htm; Thompson et al., 2005) were excluded from the analysis. We have used two kinds of solar irradiance data. The measured solar irradiance data (Frohlich, 2008) from www.pmodwrc.ch/pmod.php? topic=tsi/composite/SolarConstant and the reconstructed solar irradiance data (Lean, 2000) from ftp://ftp.ncdc.noaa.gov/pub/data/ paleo/climate_forcing/solar_variability/lean2000_irradiance.txt. The data on global $\mathrm{CO}_{2}$ emission (Marland et al., 2007) were taken from http://cdiac.ornl.gov/trends/emis/meth_reg.htm, while the global $\mathrm{CO}_{2}$ concentration measured at Mauna Loa (Keeling and Wharf, 2005) was from www.esrl.noaa.gov. The data on the cyclones over

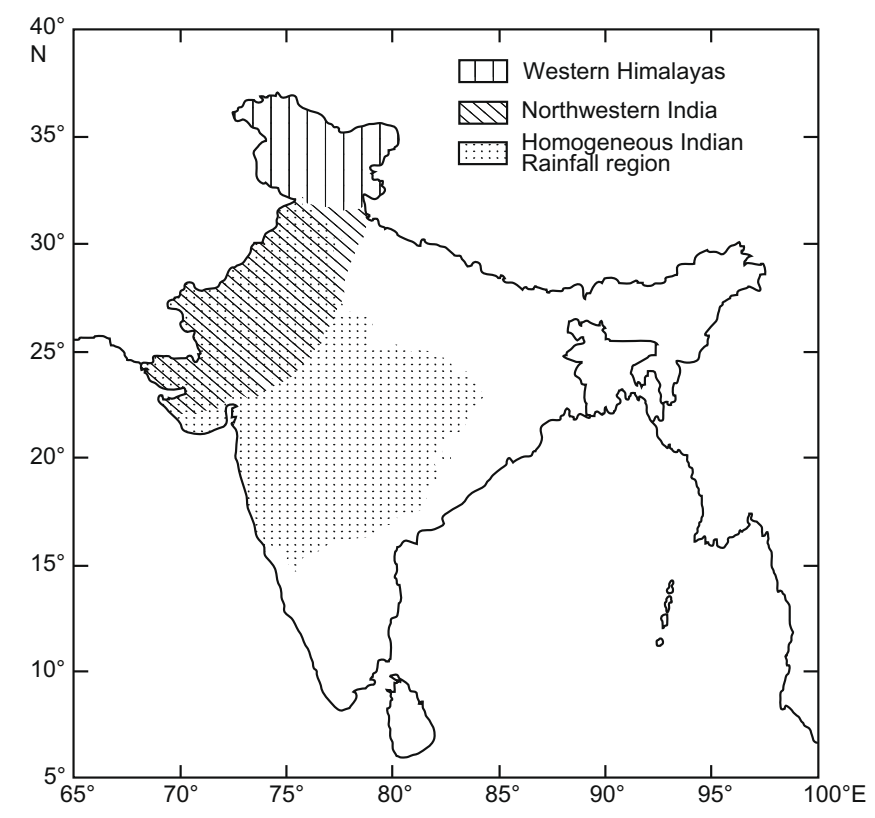

Fig. 1. Map showing geographical regions used in the study for computing spatial averages of various parameters. Region with vertical lines represent Western Himalayas and slanting lines represent the northwestern Indian region over which winter temperature data were used. The dotted region indicates the homogeneous rainfall region. The data on normalized difference vegetation index (NDVI) were used for the homogeneous rainfall region. the Arabian Sea during 1970-1999 were obtained from the India Meteorological Department (IMD) (http://www.imd.ernet.in/ section/nhac/static/cyclone-history-as.htm) while that during 2000 and 2007 were taken from the Joint Typhoon Warning Center (JTWC) https://metocph.nmci.navy.mil/jtwc/best_tracks/ 2001/2001sbio/bio012001.txt. The data for air temperature and rainfall over India (Fig. 1) during 1960 and 2005 (Parthasarathy et al., 1995; Kothawale and RupaKumar, 2005) were taken from Indian Institute of Tropical Meteorology (IITM) (http://www.tropmet.res.in). The monthly mean climatology of wind was obtained from NCEP/NCAR reanalysis (Kalnay et al., 1996) data (http:// www.cdc.noaa.gov/cdc/data.ncep.reanalysis.html).

The February temperature in northwestern India and western Himalayas (see Fig. 1 for the geographic location) was computed by averaging the air temperature from that region in February, while all India monsoon rainfall was computed by averaging for the months June to September. The 5-year running mean anomaly and integrated anomaly over the decade were calculated from the monsoon rainfall data. The wheat yield data of India during 1965 and 2005 were taken from the Statistics Division of the Food and Agriculture Organization (FAO) (http://faostat.fao.org). The normalized difference vegetation index (NDVI) (Tucker, 1979) for the homogeneous Indian rainfall region (Fig. 1) was taken from advanced very high resolution radiometer (AVHRR) for the period 1982-2002 (http://apdrc.soest.hawaii.edu). The data on the number of heat spells over India from 1978 to 2005 were taken from disastrous Weather Events published yearly by the IMD.

\section{Results and discussion}

The analysis of all the three basin-averaged annual mean SST (ICOADS, NOAA and Kaplan) anomaly of the Arabian Sea $\left(0-25^{\circ} \mathrm{N}\right.$ and $45-80^{\circ} \mathrm{E}$ ) showed dominant decadal scale variability during the period 1960-1995 (Fig. 2) with a slow warming trend. Beyond 1995, a disruption in the natural decadal cycle of SST anomaly was noticed. Since the natural decadal cycle is known to arise from solar activity (White, 2006) we examined the measured as well as reconstructed solar irradiance. It showed a smooth decadal cycle without any abrupt change during the study period (Fig. 2). The decadal cycle seen in the SST anomaly closely followed the solar irradiance cycle until the year 1995, which underscored the importance of the decade after 1995 . Note that when the solar activity was declining after the year 2000, and subsequently was at its lowest (Fig. 2), the SST anomaly did not show any decreasing trend.

On the contrary, SST anomaly was the highest. This indicated that the solar activity was not responsible for the deviation of the natural decadal cycle in SST anomaly after 1995. To understand this, we examined the atmospheric $\mathrm{CO}_{2}$ concentration measured at Mauna Loa, Hawaii, and global $\mathrm{CO}_{2}$ emission. The correlation of atmospheric $\mathrm{CO}_{2}$ concentration with all the three basin-averaged SSTs (ICOADS, NOAA and Kaplan) in the Arabian Sea was larger and highly significant during the period 1960-2006 compared to the period 1960-1995 (Table 1). Note that the Kaplan SST did not show significant correlation with atmospheric $\mathrm{CO}_{2}$ concentration prior to 1995. Similarly, though the correlation of all the three SSTs with global $\mathrm{CO}_{2}$ emission was not significant during the period 1960 and 1995, a stronger and significant correlation was noticed during the period 1960 and 2006 (Table 1).

Both these results indicated the role of human-induced warming in the disruption of natural decadal cycle and subsequent secular warming of SST after 1995. It may be noted that the $\mathrm{CO}_{2}$ driven radiative forcing during 1995 and 2005 showed a 20\% increase, the largest change for any decade in at least the last 200 years (IPCC, 2007). The observed disruption of the natural decadal cycle of SST after 1995 can thus be attributed to intrinsic ocean response, in the form of regional climate-shift, to external forcing by greenhouse gases. 


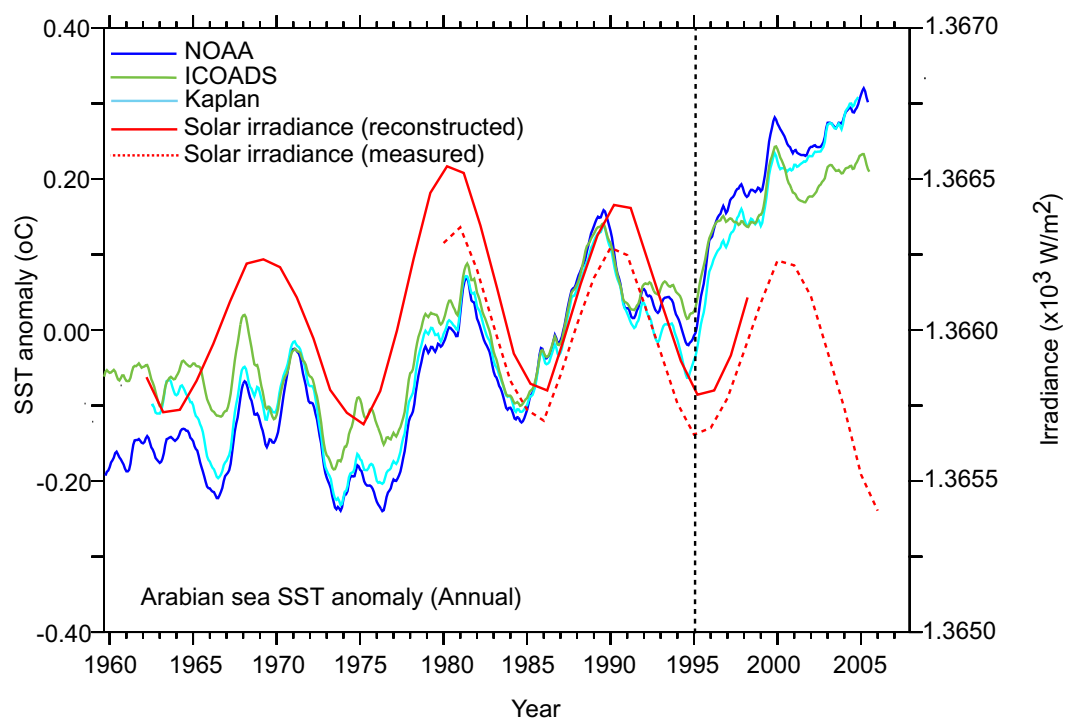

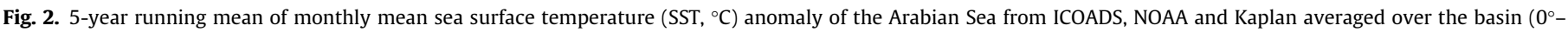
$25^{\circ} \mathrm{N}, 45^{\circ}-80^{\circ} \mathrm{E}$ ) and 5-year running mean of annual mean reconstructed as well as measured solar irradiance. See text for details.

Table 1

Correlation of basin-averaged annual mean SST (ICOADS, NOAA and KAPLAN) in the Arabian Sea with atmospheric $\mathrm{CO}_{2}$ concentration as well as global $\mathrm{CO}_{2}$ emission.

\begin{tabular}{|c|c|c|c|c|}
\hline \multirow[t]{2}{*}{ SST } & \multicolumn{2}{|c|}{$\mathrm{CO}_{2}$ concentration } & \multicolumn{2}{|c|}{$\mathrm{CO}_{2}$ emission } \\
\hline & 1960-1995 & 1960-2006 & 1960-1995 & 1960-2006 \\
\hline ICOADS & $\begin{array}{l}r=0.30 \\
P=0.04\end{array}$ & $\begin{array}{l}r=0.58 \\
P=0.0001\end{array}$ & $\begin{array}{l}r=0.34 \\
P=0.08^{*}\end{array}$ & $\begin{array}{l}r=0.53 \\
P=0.0011\end{array}$ \\
\hline NOAA & $\begin{array}{l}r=0.39 \\
P=0.04\end{array}$ & $\begin{array}{l}r=0.62 \\
P=0.00005\end{array}$ & $\begin{array}{l}r=0.34 \\
P=0.08^{*}\end{array}$ & $\begin{array}{l}r=0.53 \\
P=0.0005\end{array}$ \\
\hline KAPLAN & $\begin{array}{l}r=0.24 \\
P=0.22^{*}\end{array}$ & $\begin{array}{l}r=0.49 \\
P=0.002\end{array}$ & $\begin{array}{l}r=0.19 \\
P=0.33^{*}\end{array}$ & $\begin{array}{l}r=0.41 \\
P=0.01\end{array}$ \\
\hline
\end{tabular}

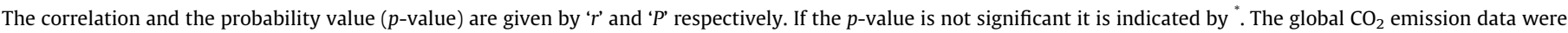
taken from: http://cdiac.ornl.gov/trends/emis/meth_reg.htm, while the global $\mathrm{CO}_{2}$ concentration measured at Mauna Loa was from: www.esrl.noaa.gov.

To understand the effect of this regional climate-shift on the ocean-atmospheric processes, we analyzed the cyclone data available for the past 37 years (1970-2007). In the Arabian Sea, cyclones are formed mainly during two periods: May-June (spring-summer transition) and October-November (fall-winter transition). The cyclones during May and June are formed within the Arabian Sea itself, while during October and November they are mostly formed over the Bay of Bengal and cross over to the Arabian Sea. Hence, we analyzed the data during May and June to identify the occurrence of the most intense cyclones in the Arabian Sea and presented the results in Table 2.

Table 2

Number of intense cyclones in the Arabian Sea during 1970-2007. A cyclone is categorized as "intense" when the wind speed associated with the cyclone exceeds $100 \mathrm{~km} \mathrm{~h}^{-1}$.

\begin{tabular}{llll}
\hline Year & Duration & Wind speed $\left(\mathrm{km} \mathrm{h}^{-1}\right)$ & Intensity $T$-number \\
\hline 1976 & May 31 - June05 & 167 & n.a \\
1996 & June 17 - June 20 & 111 & 3.5 \\
1998 & June 05 - June 09 & 167 & 5.0 \\
1999 & May 16 - May 22 & 195 & 5.5 \\
2001 & May 21 - May 28 & 210 & 5.5 \\
2007 & May 31 - June 07 & 315 & 7.0 \\
\hline
\end{tabular}

$T$-number is a measure of the intensity of a cyclone (for details, see http://www. ssd.noaa.gov/PS/TROP/CI-chart.html). n.a: data not available.
For the present study, the cyclones with wind speed greater than $100 \mathrm{~km}$ per hour were designated as "most intense cyclones". The analysis showed a five fold increase in the occurrence of intense cyclones in the Arabian Sea during the past 12 years (1995-2007), compared to the previous 25 years (1970-1995), when there was only one in 1976. In addition to the increase in the "number" of occurrence of severe cyclones the "intensity" of these cyclones also showed an increase with time as can be discerned from the $T$-number in Table 2. Such increase in the intensity and occurrence of severe cyclones in the tropics, especially in the Atlantic and Indian Oceans are reported in a warming environment (Emanuel, 2005; Webster et al., 2005; Elsner et al., 2008). However, we would like to point out that the length of our data is only 25 years.

In order to decipher further, the impact of the regional climateshift on the adjacent landmass, we analyzed the monthly mean air temperature and rainfall over India. The air temperature during February in the regions of northwestern India and western Himalayas (see Fig. 1 for location) did not show any trend during 1960 and 1995, but after 1995 it showed a rapid warming of about $1.5^{\circ} \mathrm{C}$ (Fig. 3a).

Since wheat is a winter crop and a major portion of the wheatproducing region falls within northwestern India, we analyzed the annual wheat yield $\left(\mathrm{kg} \mathrm{hectare}^{-1}\right.$ ) (Fig. 3b) which showed a steady rate of increase in the decadal yield during 1965 and 1995 (from $425 \mathrm{~kg}_{\text {hectare }}{ }^{-1}$ during $1965-1975$ to $689 \mathrm{~kg}$ hectare $^{-1}$ during 1985-1995). However, during 1995 and 2005 the decadal yield dramatically decreased to $42 \mathrm{~kg}$ hectare $^{-1}$ in synchrony with 

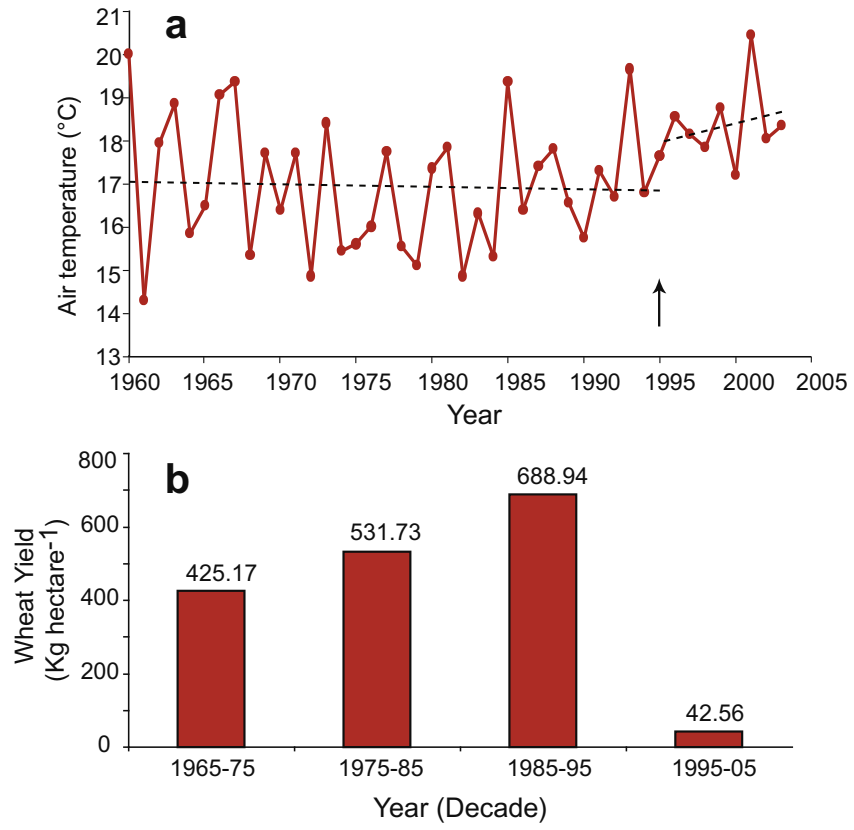

Fig. 3. (a) February mean air temperature $\left({ }^{\circ} \mathrm{C}\right)$ averaged for the northwestern India and western Himalayas, and (b) all India decadal wheat yield $\left(\mathrm{kg}_{\text {hectare }}{ }^{-1}\right)$. The broken line indicates the linear trend line.

increasing February temperature (Fig. 3a). A correlation of annual wheat yield with air temperature in February during 1960-2005 showed a significant negative correlation $(r=-0.30$ and $p$-value $=0.05$ ). The critical period for the wheat crop is its growth and reproductive stages which occur during February (Kumar and Parikh, 2001). Higher temperatures during this period lead to stress on the growth and reduce yield. It has been shown that for every $1{ }^{\circ} \mathrm{C}$ increase in temperature, the kernel weight of wheat declined up to $4.5 \%$ of the maximum predicted kernel weight at $16{ }^{\circ} \mathrm{C}$ (Saini et al., 1986). Hence, we attribute a significant portion of this 16 -fold reduction in the wheat production after 1995 to the warmer winters $\left(\sim 1.5^{\circ} \mathrm{C}\right)$. There also could be other factors responsible for the observed reduction such as change in the land area under wheat cultivation, availability of water resources, change in the usage of fertilizers, for which we do not have data.

Next we analyzed the all India summer monsoon (June-September) rainfall data. The integrated decadal anomaly showed a decline of 70.9 mm during 1995 and 2004 (Fig. 4a).

This decline was much higher than those from 1965-1975 (39.5 mm) and 1985-1995 (7.5 mm) periods. Note that during 1965 and 1975 there were 5 years of drought when the decadal anomaly was $-39.5 \mathrm{~mm}$. Again, during 1985 and 1995 there were 3 drought years and the decadal anomaly was $-7.49 \mathrm{~mm}$. Interestingly, in spite of having only 1 drought year the highest negative rainfall anomaly occurred during the period 1995-2004. It may be noted that the Indian summer monsoon is driven by the landocean thermal-contrast and a warmer ocean would weaken the Indian summer monsoon. Hence, the negative decadal anomaly in the all India summer monsoon rainfall during late 1995 appears to be linked to the weakening of land-ocean thermal-gradient under the secular warming of the Arabian Sea (Fig. 2). Since more than $80 \%$ of the rainfall over India occurs during summer monsoon, it is expected to have a major influence on the vegetation cover. We analyzed the normalized difference vegetation index (NDVI) for the homogeneous Indian monsoon rainfall region (see Fig. 1 for location). The NDVI showed an increasing trend from 1982 to 1995 and after 1995, the trend reversed showing a general decrease (Fig. 4 b). We attribute a major part of this declining vegeta-
All India Summer monsoon (JJAS) Rainfall anomaly
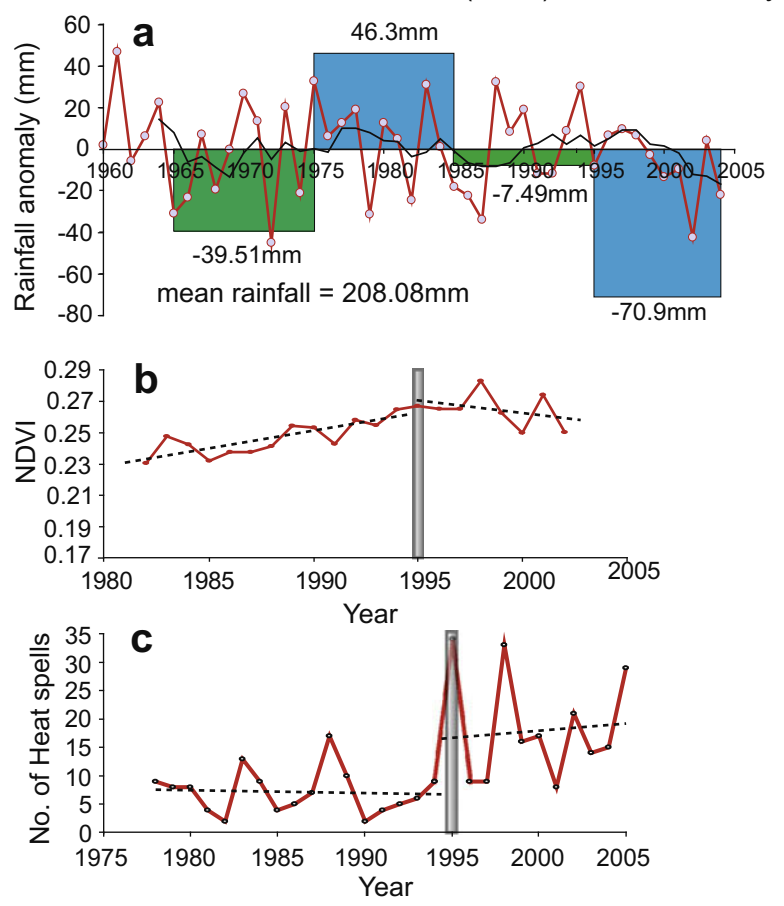

Fig. 4. (a) All India summer-monsoon rainfall anomaly (red curve), 5-year running mean (black curve), integrated decadal rainfall anomaly (bar diagram), (b) normalized difference vegetation index (NDVI) for the homogeneous Indian rainfall region, and (c) number of heat spells over India. The broken line indicates the linear trend line. (For interpretation of the references in colour in this figure legend, the reader is referred to the web version of this article.)

tion cover to declining summer monsoon rainfall. Though human induced changes such as deforestation could also alter the vegetation cover, its contribution is presumably much smaller. Since it is generally known that changes in the land cover can magnify the effect of extreme climate events, we examined the data on the occurrence of heat spells over India during the period 1978-2005. The number of heat spells during 1978-1995 was below 20, but after 1995 it showed a sudden increase up to 35 (Fig. 4c).

Thus, we see a close link between the disruption of the natural decadal cycle of SST in the Arabian Sea after 1995 and the events such as increased occurrence of "most intense" cyclones, warming winters, decreased decadal monsoon rain fall, decreased vegetation cover and increased number of heat spells. Some of these changes may be interacting to strengthen/weaken the others through positive/negative feedbacks in the ocean-atmosphere-land system. We attribute these changes to warming driven by increased $\mathrm{CO}_{2}$ emission. The obvious question is why the Arabian Sea showed a climate change response only after 1995, though the global $\mathrm{CO}_{2}$ emission and atmospheric $\mathrm{CO}_{2}$ concentrations showed an increasing trend from 1958 onwards. The answer may lie in the geographic location of the Arabian Sea and its special oceanographic feature. As mentioned earlier, this tropical basin experiences strong wind-driven upwelling during summer monsoon (Swallow, 1984; Smith and Bottero, 1977; Smith and Codispoti, 1980) along the coasts of Somalia, Arabia and the southwest coast of India. Upwelling supplies cold and nutrient-rich subsurface waters to the surface which subsequently moves offshore under the influence of prevailing currents (Prasanna Kumar et al., 2001b). For example, the temperature of the upwelled water in the Somali region is about $17-22{ }^{\circ} \mathrm{C}$ (Smith and Codispoti, 1980) and advection carries these waters to the central Arabian Sea. Thus, the upwelling of cold subsurface waters and its advection to offshore region cools a large part of the Arabian Sea. It is this upwelling-driven cooling 


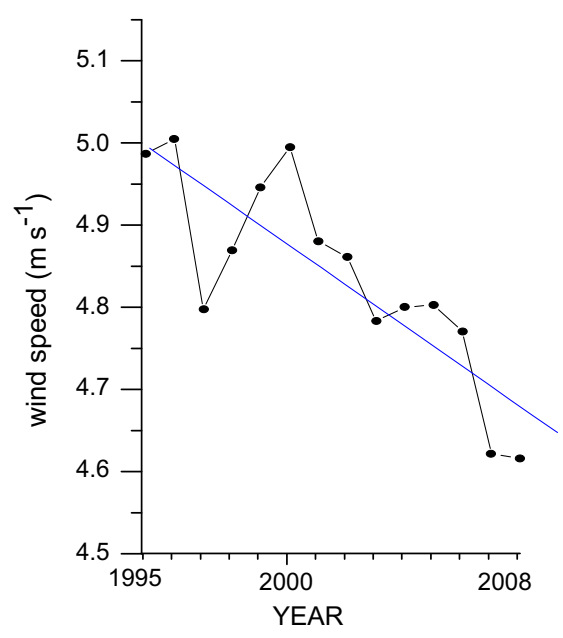

Fig. 5. Basin-averaged annual mean winds in the Arabian Sea during 1995-2008 from NCEP/NCAR reanalysis data. See text for details. The solid line is the linear trend line with $r=-0.83$ and $p$-value of 0.0002 .

that was able to offset the increased SST and maintain the natural decadal cycle until 1995. But after 1995, the basin-wide winds in the Arabian Sea showed a decline (Fig. 5).

However, after 1995 the $\mathrm{CO}_{2}$ driven radiative forcing showed a 20\% increase during 1995 and 2005 (IPCC, 2007) and the upwelling-driven cooling in the Arabian Sea was unable to compensate the oceanic response of warming in the Arabian Sea. This led to the observed disruption in the natural decadal cycle of SST and subsequent secular warming.

\section{Summary and conclusion}

Using a suite of multi-disciplinary data from the Arabian Sea and the adjacent landmass, we explored the signature of global warming and showed that the disruption in the natural decadal cycle of SST after 1995 is a manifestation of regional climate-shift. Concurrent with this, a five fold increase in the occurrence of most intense cyclones as well as an increase in their intensity was noticed. The winters over the northern part of the Indian landmass showed a rapid warming consistent with the increase in SST which resulted in a 16-fold decrease in the decadal wheat production after 1995. The all India summer monsoon rainfall anomaly showed a sharp decline after 1995, which was linked to the decline in vegetation cover. Concomitant with this, the number of heat spells showed a sharp increase after 1995 . We propose that the upwelling-driven cooling in the Arabian Sea was able to maintain the natural decadal cycle in the SST until 1995, in spite of the oceanic thermal inertia as well as increased global $\mathrm{CO}_{2}$ emission and atmospheric $\mathrm{CO}_{2}$ concentrations. After 1995 the upwelling-driven cooling was unable to offset the $\mathrm{CO}_{2}$-driven warming seen in the SST.

The present study illustrate the correlation between components in the ocean-atmosphere-land processes and indicates complicated feedbacks in the Arabian Sea and the adjacent landmass, which has implications for the food and water security of this region. The quantification of these changes is a big challenge. We do not know as yet, how long the observed trend will continue. There is an urgent need to assemble more data and follow a multi-disciplinary approach to analyze them.

\section{Acknowledgements}

The authors wish to express their gratitude to Prof. Lucy James, Department of English, Government College of Arts, Science and
Commerce, Sanquelim, Goa for meticulously going through the manuscript and suggesting language corrections. We thank Dr. Ragu Murtugudde of University of Maryland, USA for his constructive criticism of the manuscript and suggestions, Mr. O.P. Sreejith, IMD, Pune for making available the data on Disastrous Weather Events, Mr. Byju for processing the wind data, Dr. P. Vethamony and Dr. G.N. Swamy of NIO, Goa for discussions, Mr. Shyam and Mr. Uchil for the help in preparing the diagrams. We also wish to acknowledge Director NIO Goa and Council of Scientific and Industrial Research (CSIR), New Delhi for all the support and encouragement. Authors Roshin and Jayu acknowledge CSIR for their fellowships. The authors thank the anonymous reviewers for their constructive criticism which helped to improve the manuscript. This is NIO contribution number 4558 .

\section{References}

Banse, K., 1987. Seasonality of phytoplankton chlorophyll in the central and northern Arabian Sea. Deep-Sea Research 34, 713-723.

Barnett, T.P., Pierce, D.W., AchutaRao, K.M., Gleckler, P.J., Santer, B.D., Gregory, J.M., Washington, W.M., 2005. Penetration of human-induced warming into the world's oceans. Science 309, 284-287.

Both, C., Bouwhuis, S., Lessells, C.M., Visser, M.W., 2006. Climate change and population declines in a long-distance migratory bird. Nature 441, 81.

Brock, J.C., McClain, M.C., 1992. Interannual variability in phytoplankton blooms observed in the northwestern Arabian Sea during the southwest monsoon. Journal of Geophysical Research 97, 733-750.

Church, J.A., 2001. How fast are sea levels rising? Science 294, 802-803.

Cramer, W., Bondeau, A., Woodward, F.I., Prentice, I.C., Betts, R.A., Brovkin, V., Cox, P.M., Fisher, V., Foley, J.A., Friend, A.D., Kucharik, C., Lomas, M.R., Ramankutty, N., Sitch, S., Smith, B., White, A., Young-Molling, C., 2001. Global response of terrestrial ecosystem structure and function to $\mathrm{CO}_{2}$ and climate change: results from six dynamic global vegetation models. Global Change Biology 7, 357-373. doi:10.1046/j.1365-2486.2001.00383.x.

Elsner, J.B., Kossin, J.P., Jagger, T.H., 2008. The increasing intensity of the strongest tropical cyclones. Nature 455, 92-95.

Emanuel, K., 2005. Increasing destructiveness of tropical cyclones over the past 30 years. Nature 436, 686-688.

Frohlich, C., 2008. Solar Constant: Construction of a composite total solar irradiance (TSI) time series from 1978 to present. On line at: PhysikalischMeteorologisches Observatorium Davos. <www.pmodwrc.ch/ pmod.php?topic=tsi/composite/SolarConstant>

Goswami, B.N., Venugopal, V., Sengupta, D., Madhusoodhanan, M.S., Xavier, P.K., 2006. Increasing trend of extreme rains over India in a warming environment. Science 314, 1442-1445.

Hoegh-Guldberg, O., Mumby, P.J., Hooten, A.J., Steneck, R.S., Greenfield, P., Gomez, E., Harvell, C.D., Sale, P.F., Edwards, A.J., Caldeira, K., Knowlton, N., Eakin, C.M., Lglesias-Prieto, R., Muthiga, N., Bradbury, R.H., Dubi, A., Hatziolos, M.E., 2007. Coral reefs under rapid climate change and ocean acidification. Science 318 , 1737-1742.

Hopp, M.J., Foley, J.A., 2003. Worldwide fluctuations in dengue fever cases related to climate variability. Climate Research 25, 85-94.

Hughes, T.P., Baird, A.H., Bellwood, D.R., Card, M., Connolly, R., Folke, C., Grosberg, R. Hoegh-Guldberg, O., Jackson, J.B.C., Kleypas, J., Lough, J.M., Marshall, P., Nystrom, M., Palumbi, S.R., Pandolfi, J.M., Rosen, B., Roughgarden, J., 2003. Climate, human impacts, and the resilience of coral reefs. Science 301, 929-933.

IPCC, 2007. Climate Change 2007: The physical science basis. Contribution of working group I to the forth assessment report of the intergovernmental panel on climate change. In: Solomon, S., Qin, D., Manning, M., Chen, Z., Marquis, M., Averyt, K.B., Tignor, M., Miller, H.L., (Eds.), Cambridge University Press, Cambridge, UK. p. 996.

Kaplan, A., Cane, M., Kushnir, Y., Clement, A., Blumenthal, M., Rajgopalan, B., 1998. Analyses of global sea surface temperature 1856-1991. Journal of Geophysical Research 103, 18567-18589.

Kothawale, D.R., Rupa Kumar, K., 2005. On the recent changes in surface temperature trends over India. Geophysical Research Letters 32 (L18714), 1-4.

Kumar, K.S.K., Parikh, J., 2001. Indian agriculture and climate sensitivity. Global Environmental Change 11, 147-154.

Lean, J., 2000. Evolution of sun's spectral irradiance since the maunder minimum. Geophysical Research Letters 27, 2425-2428.

Kalnay, E., Kanamitsu, M., Kistlet, R., Collins, W., Deaven, D., Gandin, L., Iredell, M., Saha, S., White, G., Woollen, J., Zhu, Y., Chelliah, M., Higgins, W., Janowiak, J., Mo, K.C., Ropelewski, C., Wang, J., Leetmaa, A., Reynolds, R., Jenne, R., Joseph, D., 1996. The NCEP/NCAR 40-year reanalysis project. Bulletin of American Meteorological Society 77, 437-471.

Keeling, C.D., Wharf, T.P., 2005. Atmospheric $\mathrm{CO}_{2}$ records from sites in the SIO air sampling network. In: Trends: a compendium of data on global change. On line at: Carbon Dioxide Information Analysis Center, Oak Ridge National Laboratory, US Department of Energy, Oak Ridge, Tenn, USA; WDCGC, 2007, Mauna Loa (NOAA/GMD), on line at: World Data Centre for Greenhouse Gases. <http:// cdiac.oml.gov/trends/co2/sio-mlo.htm>. 
Madhupratap, M., Prasanna Kumar, S., Bhattathiri, P.M.A., Kumar, M.D., Raghukumar, S., Nair, K.K.C., Ramaiah, N., 1996. Mechanism of the biological response to winter cooling in the northeastern Arabian Sea. Nature 384, 549-552.

Marland, G., Boden, T.A., Andres, R.J., 2007. Global, regional, and national fossil fuel $\mathrm{CO}_{2}$ emissions. In: Trends: A Compendium of Data on Global Change. Carbon Dioxide Information Analysis Center, 37831-6335, Oak Ridge National Laboratory, US Department of Energy, Oak Ridge, Tennessee, USA.

Meehl, G.A., Washington, W.M., Collins, W.D., Arblaster, J.M., Hu, A., Buja, L.E. Strand, W.G., Teng, H., 2005. How much more global warming and sea level rise? Science 307, 1769-1772.

Meyer, J.L., Sale, M.J., Mulholland, P.J., Poff, N.L., 1999. Impacts of climate change on aquatic ecosystem functioning and health. Journal of the American Water Resources Association 35, 1373-1386. doi:10.1111/j.1752-1688.1999. tb04222.x.

Oerlemans, J., 1994. Quantifying global warming from the retreat of glaciers. Science 264, 243-245.

Parthasarathy, B., Munot, A.A., Kothawale, D.R., 1995. All India monthly and seasonal rainfall series: 1871-1993. Theoretical and Applied Climatology 49, 217-224.

Prasanna Kumar, S., Ramaiah, N., Gauns, M., Sarma, V.V.S.S., Muraleedharan, P.M., Raghukumar, S., Kumar, M.D., Madhupratap, M., 2001a. Physical forcing of biological productivity in the Northern Arabian Sea during the Northeast Monsoon. Deep-Sea Research II 48, 1115-1126.

Prasanna Kumar, S., Madhupratap, M., Kumar, M.D., Muraleedharan, P.M., de Souza, S.N., Gauns, M., Sarma, V.V.S.S., 2001b. High biological productivity in the central Arabian Sea during the summer monsoon driven by Ekman pumping and lateral advection. Current Science 81, 1633-1637.

Reynolds, R.W., Rayner, N.A., Smith, T.M., Stoke, D.C., Wang, W., 2002. An improved in situ and satellite SST analysis for climate. Journal of Climate 15, 1609-1625.

Rogers, D.J., Randolph, S.E., 2000. The global spread of malaria in a future, warmer world. Science 289, 1763-1766.

RupaKumar, R., KrishnaKumar, K., Ashrit, R.G., Patwardhan, S.K., Pant, G.B., 2002. Climate change in India: observations and model projections. In: Shukla, P.R.
Sharma, S.K., Venkata Ramana, P. (Eds.), Climate Change and India: Issues, Concerns and Opportunities. Tata McGraw-Hill Publishing Company Limited, New Delhi.

Ryther, J.H., Hall, J.R., Pease, A.K., Bakun, A., Jones, M.M., 1966. Primary organic production in relation to the chemistry and hydrography of the western Indian Ocean. Limnology and Oceanography 11, 371-380.

Saini, A.D., Dadwal, V.K., Phadnawis, B.N., Nanda, R., 1986. Thermal and photoperiodic effects on phase durations of four wheat varieties grown on different sowing dates. Indian Journal of Agriculture Science 56, 646-656.

Smith, R.L., Bottero, J.S., 1977. On upwelling in the Arabian Sea. In: Angel, M. (Ed.), A Voyage of Discovery. Percamon Press, New York. pp. 291-304.

Smith, S.L., Codispoti, L.A., 1980. Southwest monsoon of 1979: chemical and biological response of Somali coastal waters. Science 209, 597-600.

Swallow, J.C., 1984. Some aspects of the physical oceanography of the Indian Ocean Deep Sea Research 31, 639-650.

Thompson, B., Gnanaseelan, C., Salvekar, P.S., 2005. Indian Ocean Dipole simulation using modular ocean model. Contribution from IITM, Research Report No. RR108, ISSN: 0252-1075, p. 36.

Tucker, C.J., 1979. Red and photographic infrared linear combinations for monitoring vegetation. Remote Sensing of Environment 8, 127-150.

Webster, P.J., Holland, G.J., Curry, J.A., Chang, H.R., 2005. Changes in tropical cyclone number, duration, and intensity in a warming environment. Science 309, 18441846.

Woodruff, S.D., Diaz, H.F., Worley, S.J., Reynolds, R.W., Lubker, S.J., 2005. Early ship observational data and ICOADS. Climatic Change 73, 169-194.

White, W.B., 2006. Response of tropical global ocean temperature to the Sun's quas decadal UV radiative forcing of the stratosphere. Journal of Geophysical Research 111, 1-14.

Zhang, X., Zwiers, F.W., Hegerl, G.C., Lambert, F.H., Gillett, N.P., Solomon, S., Stott, P.A., Nozawa, T., 2007. Detection of human influence on twentieth-century precipitation Trends. Nature 448, 461-465. 